\title{
Pengaruh Cahaya Light Emiting Diode (LED) di Malam Hari terhadap Kortisol Serum dan Parameter Hematologi pada Tikus Wistar Jantan
}

\section{The Effects of Light Emitting Diode (LED) Lighting at Night on Serum Cortisol and Hematology of Male Wistar Rats}

\author{
Nila Ardilla Arief ${ }^{1}$, Aryadi Arsyad ${ }^{2}$, Irfan Idris ${ }^{3}$ \\ ${ }^{1}$ Magister Program Biomedik, Universitas Hasanuddin, Indonesia \\ ${ }^{2,3}$ Fakultas Kedokteran, Universitas Hasanuddin, Indonesia
}

\section{ARTICLE INFO}

\section{Article history}

Received date 10 Sep 2021

Revised date 20 Sep 2021

24 Sep 2021

Accepted date

09 Nov 2021

Keywords:

Circadian rhythms;

Cortisol;

Lighting;

LED;

Hematology.

\section{Kata kunci:}

Irama sirkadian;

Kortisol;

Cahaya;

LED;

Hematologi.

\section{ABSTRACT/ ABSTRAK}

This modern era has changed the pattern of how humans do their daily activities in 24 hours. The pattern change includes time-shifting, most human activities now are performed at night. The consequences of the changes in human activities pattern and the increase of artificial lighting use in the night were assumed unhealthy, but how the mechanism worked was not identified yet. This was an experimental study conducted on male Wistar rats aged 12-16 weeks which were divided into 4 categories: 1 intervention group exposed for 15 days, 1 intervention group exposed for 30 days, and 2 control groups for each time exposure, light intensity 1200lux. At the end of exposures, the blood samples were taken from rats that had been anesthetized before by using ether. Then blood samples were taken to analyze their cortisol levels using the Enzyme-linked immunosorbent assay(ELISA) method and the hematology was examined through autoanalyzer Abaxis. The data were analyzed using an independent T-test and MannWhitney test and considered significant if $p$-value $<0,05$. Overall, the cortisol and hematology levels indicated, especially Red Blood Cell (RBC), Mean Corpuscular Hemoglobin Concentration (MCHC), and neutrophil specifically for the group which had been exposed by LED lighting for 30 days.

\begin{abstract}
Zaman modernisasi saat ini mengubah pola aktivitas manusia dalam sehari, dalam rentang waktu 24 jam. Banyak pola aktivitas manusia yang bergeser ke malam hari, sehingga terjadi peningkatan aktivitas dan peningkatan penggunaan cahaya buatan pada malam hari. Akibat pergeseran pola aktivitas dan peningkatan penggunaan cahaya buatan di malam hari diduga dapat memberikan dampak buruk pada kesehatan, tetapi mekanisme yang mendasari belum sepenuhnya dipaham. Penelitian ini adalah penelitian eksperimental, menggunakan tikus wistar jantan berumur 12-16 minggu sebanyak 24 ekor yang dibagi ke dalam 4 kelompok perlakuan berdasarkan waktu terpaparnya yaitu 15 hari dan 30 hari, yang masing-masing terdiri dari 1 kelompok kontrol dan 1 kelompok perlakuan. Intensitas cahaya yang digunakan dalam penelitian ini adalah sebesar 1500lux. Pada akhir pemaparan diambil sampel darah tikus melalui ekor tikus, untuk dianalisis kadar kortisolnya dengan menggunakan metode Enzyme-linked immunosorbent assay (ELISA) dan pemeriksaan hematologi dengan hematologi autoanalyzer abaxis. Data yang diperoleh dianalisa dengan Independent t-test dan Mann-Whitney, dan dinyatakan signifikan jika $p$-value $<0,05$. Secara keseluruhan hampir semua parameter hematologi dan hormon kortisol pada kelompok 15 hari tidak ada perbedaan yang signifikan dengan $p$-value $>0,05$, sedangkan untuk kelompok yang dipaparkan cahaya LED selama 30 hari menunjukkan perbedaan yang $\operatorname{signifikan}(p$-value $<0,05)$ terhadap kadar hormon kortisol, dan parameter hematologi khususnya Red Blood Cell (RBC), dan Mean Corpuscular Hemoglobin Concentration (MCHC), dan Neutrophil.
\end{abstract}




\section{PENDAHULUAN}

Cahaya buatan merupakan kebutuhan masyarakat di zaman modernisasi saat ini, karena cahaya buatan dapat memberikan keamanan dan kenyamanan, dan cahaya buatan juga dapat berfungsi sebagai sumber relaksasi, dan untuk meningkatkan kewaspadaan dan produktivitas, tapi cahaya buatan diduga dapat memberikan efek buruk pada manusia, hewan, dan tumbuhan maupun keseimbangan ekosistem (Tähkämö \& Halonen, 2015; Tähkämö, Martinsons, Ravel, Grannec, \& Zizzis, 2014). Cahaya buatan yang paling banyak digunakan saat ini yaitu lampu $L E D$ (Light Emiting Diode). LED ini digunakan secara luas karena dikenal hemat energi, lebih murah dan tahan lama serta cahaya yang dihasilkan sangat terang. Lampu LED ini dipercaya dapat menghemat daya listrik $85 \%$ lebih rendah, oleh karena itu lampu ini semakin banyak digunakan dibandingkan jenis lampu lainnya (Russart \& Nelson, 2018).

Lampu LED yang dikenal hemat energi ini rupanya memiliki efek negative pada manusia maupun ekosistem. Jenis lampu ini menghasilkan spektrum biru yang dapat mengganggu ritme sirkadian dan menekan melatonin bahkan jika cahayanya tidak terlalu terang, terutama jika paparannya terjadi di malam hari. Cahaya di malam hari akan menekan melatonin dan mempengaruhi metabolisme, sekresi hormon, ekspresi gen dan aktivitas enzim (Fonken, Kitsmiller, Smale, \& Nelson, 2012). Baik pada manusia maupun hewan pengerat sangat responsif terhadap panjang gelombang biru. Cahaya biru akan mengganggu gen Cycle Output Locomotor Circadian caput(clock) yang akan menyebabkan gangguan yang berhubungan dengan kesehatan fisik maupun mental seperti gangguan neuroimun,gangguan reproduksi, gangguan metabolisme, seperti obesitas, diabetes tipe 2, hipertensi bahkan kanker (Fonken, Aubrecht, Meléndez-Fernández, Weil, \& Nelson, 2013).

Penggunaan cahaya pada malam hari dapat mengganggu, karena organisme tidak siap secara fisiologis untuk menghadapi sinyal cahaya pada malam hari. Cahaya akan ditangkap oleh mata dan diubah menjadi sinyal listrik oleh reseptor retina dan melalui saraf optik ke area otak yang penting untuk penglihatan, fungsi otonom, dan pengaturan waktu sirkadian (Opperhuizen, et al., 2017). Cahaya merupakan isyarat utama bagi jam sirkadian untuk menyinkronkan aktivitas ritmik yang dihasilkan secara endogen dengan siklus siang/malam lingkungan (Bedrosian \& Nelson, 2017). Paparan cahaya di malam hari dapat mengubah ekspresi gen jam sirkadian di hipotalamus dan mempengaruhi ekspresi gen di organ perifer dan terbukti bisa mempengaruhi system endokrin terutama hormon melatonin dan kortisol (Rohling, vanderLeest, Michel, Vansteensel, \& Meijer, 2011; Gnocchi \& Bruscalupi, 2017; Fonken \& Nelson, 2014).

Irama sirkadian dikontrol oleh pacemaker yang terletak pada bagian ventral anterior dari hipotalamus, yaitu Suprachiasmatic Nuclei (SCN). Pada mamalia, irama sirkadian terutama dikendalikan oleh Suprachiasmatic Nuclei (SCN) (Sherwood, 2019). Cahaya yg diterima oleh SCN sebelumnya akan diterima oleh fotoreseptor khusus retina, yaitu melanopsin yang merupakan suatu protein yang terdapat di sel khusus ganglion retina, yang menjaga tubuh agar tetap sinkron dengan waktu eksternalnya (Nelson \& Chbeir, 2018).

Secara khusus, akibat paparan cahayan buatan (LED) di malam hari terutama pada pekerja shift berdasarkan beberapa penelitian bisa menyebabkan peningkatan risiko penyakit kardiovaskular (Welsh, et al., 2012), sindrom metabolik dan diabetes mellitus tipe II (Rumanova, Okuliarova, \& Zeman, 2020). Selain itu, penelitian pada hewan pengerat menunjukkan bahwa akibat paparan cahaya buatan di malam hari dapat menyebabkan disregulasi system kekebalan, dan bahkan terdapat penelitian pada hewan pengerat dengan cukup pencahayaan redup di malam hari bisa menyebabkan gangguan metabolisme dan obesitas (Rumanova, et al., 2020; Vinogradova \& Anisimov, 2013). Berdasarkan uraian di atas, penelitian ini bertujuan untuk mengetahui atau menganalisis kadar kortisol dan hematologi pada tikus wistar jantan yang diberikan paparan cahaya buatan (LED) di malam hari.

\section{METODE}

Studi eksperimental dilakukan dengan menggunakan Post-test Only Control Group Design. Hewan yang digunakan untuk percobaan adalah tikus wistar jantan yang dipelihara atau dibudidayakan di Laboratorium Biofarmasi dan Toksikologi Fakultas Farmasi Universitas Hasanuddin. Tikus yang berusia 12-16 minggu dengan berat badan $\pm 200 \mathrm{gr}$ dan diaklimatisasi selama 3 minggu dengan siklus pencahayaan terang-gelap (12L:12D). Selama aklimatisasi tikus diberi pakan standar (AD2) sekali sehari sebanyak 130-140 gr tiap kandang dan air secara ad libitum. Penelitian dilakukan di laboratorium penelitian Rumah Sakit Universitas Hasanuddin. Penelitian ini telah mendapat persetujuan dari Komite Etik Penelitian Kesehatan Fakultas 
Kedokteran Universitas Hasanuddin dengan nomor registrasi UH21020076.

Tikus yang telah diadaptasikan dan memenuhi kriteria inklusi dibagi berdasarkan waktu paparannya yaitu kelompok 15 hari dan kelompok 30 hari yang masing-masing terdiri dari 1 kelompok kontrol dan 1 kelompok perlakuan. Hewan percobaan dibuatkan semacam kandang khusus yang terbuat dari balok dan tripleks sebanyak 2 buah. Kandang pertama digunakan sebagai tempat kelompok kontrol dan kandang kedua digunakan sebagai tempat kelompok perlakuan. Kandang kelompok perlakuan dipasang lampu LED dengan pencahayaan sekitar 1500lux. Kandang diberi celah-celah disetiap sisinya agar udara dan cahaya di siang hari dapat masuk ke dalam kandang.

Sebelum tikus dimasukkan ke dalam kandang khusus yang terbuat dari tripleks dan balok, tikus terlebih dahulu ditempatkan dalam kandang yang terbuat dari bahan plastik berukuran $51 \times 31 \times 21 \mathrm{~cm}$ untuk mengelompokkan tikus berdasarkan waktu perlakuannya. Setiap kandang berisi 6 ekor tikus, beralaskan sekam dan diberi penutup anyaman kawat. Tikus yang masuk kelompok kontrol dipelihara dalam siklus pencahayaan terang-gelap normal (12L:12D) selama 15 hari dan 30 hari. Cahaya disini hanya berasal dari sinar matahari ketika siang hari dan saat malam hari kandang akan ditutup oleh kain hitam untuk mencegah adanya cahaya yang tidak diinginkan yang dapat masuk kedalam kandang.

Tikus yang masuk kelompok perlakuan dipelihara dalam siklus pencahayaan terangterang (12L:12L) selama 15 hari dan 30 hari. Ketika siang hari cahaya berasal dari sinar matahari (cahaya alami) dan ketika malam hari hewan coba akan dipaparkan cahaya lampu LED putih dengan intensitas 1500lux yang dirakit secara paralel. Lampu LED yang digunakan adalah jenis lampu LED putih (cool white) 18 watt dengan suhu cahaya $7000 \mathrm{~K}$ sebanyak 2 buah. Pencahayaan 1500lux pada ruangan kandang kelompok perlakuan didapatkan melalui rumus perhitungan berikut:

$$
\mathrm{N}=\frac{\mathrm{Ex} \mathrm{L} \mathrm{W}}{\emptyset \times \operatorname{LLF} \times \mathrm{CU} \times \mathrm{n}}
$$

Ket:

$\mathrm{N}=$ Jumlah titik lampu

$\mathrm{E}=$ Kuat penerangan $(\operatorname{Lux})$

$\mathrm{L}=$ Panjang $($ Length $)$

$\mathrm{W}=$ Lebar $($ Width $)$

$\varnothing=$ Total pencahayaan lampu dalam satuan lumen

LLF $=$ Loss Light Factor (kerugian cahaya), nilainya antara $0,7-0,8$

$\mathrm{CU}=$ Coeffesien of Uttilization, nilainya $50 \%$ atau 0,5

$\mathrm{N}$ = Jumlah lampu dalam 1 titik.
Tikus dianestesi dengan menggunakan eter kemudian dilakukan pengambilan darah di di bagian ekor tikus untuk pemeriksaan hematologi dan kortisol. Untuk analisis kortisol mengunakan Elisa Kit BT-Lab, dan pemeriksaaan hematologi menggunakan hematologi autoanalyzer abaxis.

Data dianalisis dengan software statistik dan dinyatakan dengan mean \pm standar deviasi. Untuk mengetahui ada tidaknya perbedaan secara signifikan antara kelompok kontrol dan perlakuan dilakukan uji independent t-test. Untuk data yang tidak memenuhi distribusi normalitas dianalisis dengan menggunakan uji MannWhitney.

\section{HASIL}

\section{Analisis Kadar Kortisol Akibat Paparan Cahaya LED di Malam Hari}

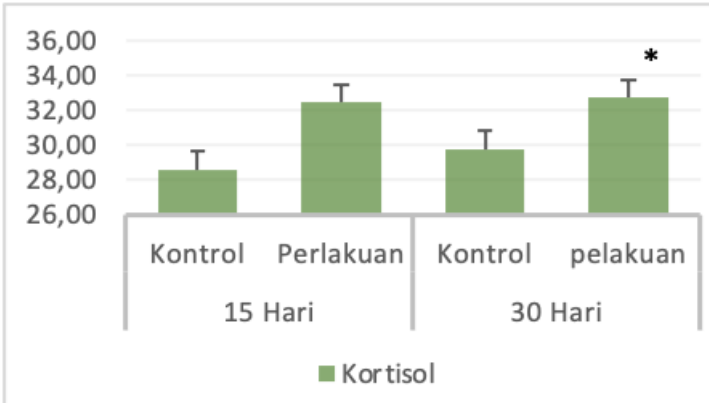

\section{Gambar 1. Hasil analisis kadar kortisol}

Berdasarkan gambar 1, rerata kadar kortisol kelompok kontrol yang tidak mendapat paparan cahaya LED pada malam hari selama 15 hari adalah 28,63 $\pm 2,78 \mathrm{ng} / \mathrm{ml}$. Namun, paparan cahaya LED di malam hari selama 15 hari pada tikus kelompok perlakuan sedikit meningkatkan kadar kortisol rata-rata menjadi $32,48 \pm 6,37 \mathrm{ng} / \mathrm{ml}$ ( $p$-value $>0,5)$. Sementara itu, kelompok yang diberikan cahaya LED di malam hari selama 30 hari juga menunjukkan sedikit peningkatan rerata kadar kortisol kelompok perlakuan $(32,77 \pm 1,60 \mathrm{ng} / \mathrm{ml})$ dibandingkan dengan kelompok kontrol $(29,80 \pm 1,83 \mathrm{ng} / \mathrm{ml})$, dengan nilai $p$-value $<0,05 \mathrm{Hal}$ ini menunjukkan terdapat perbedaan yang signifikan pada kelompok perlakuan yang diberikan cahaya LED pada malam hari selama 30 hari. 
Analisis Hematologi Akibat Paparan Cahaya LED di Malam Hari

Tabel 1. Hasil Analisis Hematologi Kelompok 15 hari

\begin{tabular}{|c|c|c|c|}
\hline \multirow[t]{2}{*}{ Variabel (Hematologi) } & $\begin{array}{c}\text { Kontrol } 15 \text { hari } \\
(\mathrm{n}=6)\end{array}$ & $\begin{array}{l}\text { Perlakuan } 15 \text { hari } \\
(n=6)\end{array}$ & \multirow[t]{2}{*}{ p-value } \\
\hline & Mean $\pm \mathrm{SD}$ & Mean $\pm \mathrm{SD}$ & \\
\hline WBC(White Blood Cell $)$ & $14.97 \pm 5.19$ & $9.80 \pm 2.49$ & $0.052 *$ \\
\hline LYM(limfosit $)$ & $76.93 \pm 11.30$ & $74.78 \pm 6.00$ & $0.689 *$ \\
\hline $\operatorname{MON}($ monosit $)$ & $14.67 \pm 4.89$ & $17.23 \pm 3.46$ & $0.319 *$ \\
\hline NEU(Neutrofil) & $4.78 \pm 5.39$ & $3.68 \pm 2.01$ & $0.688 * *$ \\
\hline EOS(Eosinofil) & $2.75 \pm 0.92$ & $3.23 \pm 0.65$ & $0.322 *$ \\
\hline BAS(Basofil) & $0.92 \pm 0.31$ & $1.08 \pm 0.21$ & $0.321 *$ \\
\hline RBC(Red Blood Cell $)$ & $5.03 \pm 0.32$ & $4.99 \pm 0.23$ & $0.831^{*}$ \\
\hline HGB(Hemoglobin) & $10.97 \pm 0.97$ & $11.53 \pm 0.60$ & $0.251 *$ \\
\hline HCT(Hematokrit) & $22.73 \pm 1.43$ & $22.67 \pm 1.51$ & $0.939 *$ \\
\hline MCV(Mean Corpuscular Volume) & $45.27 \pm 1.06$ & $45.38 \pm 1.35$ & $0.871 *$ \\
\hline MCH(Mean corpuscular Hemoglobin) & $21.80 \pm 0.98$ & $23.17 \pm 1.53$ & $0.095^{*}$ \\
\hline $\mathrm{MCHC}$ & $48.20 \pm 2.27$ & $51.07 \pm 3.68$ & $0.136^{*}$ \\
\hline PLT (Platelet $) /$ trombosit & $679.00 \pm 75.99$ & $730.33 \pm 101.11$ & $0.344^{*}$ \\
\hline$R D W-C V$ & $14.98 \pm 1.41$ & $14.60 \pm 1.50$ & $0.658^{*}$ \\
\hline$R D W-S D$ & $33.88 \pm 3.13$ & $33.13 \pm 4.18$ & $0.732 *$ \\
\hline MPV(Mean Platelet Volume) & $6.22 \pm 0.23$ & $6.03 \pm 0.21$ & $0.179 *$ \\
\hline PDW(Platelet Distribution Width) & $5.70 \pm 0.50$ & $5.30 \pm 0.52$ & $0.202 *$ \\
\hline PCT(Plateletcrit) & $0.42 \pm 0.06$ & $0.44 \pm 0.07$ & $0.563^{*}$ \\
\hline
\end{tabular}

Tabel 2. Hasil Analisis Hematologi Kelompok 30 Hari

\begin{tabular}{lrrr}
\hline \multirow{2}{*}{ Variabel (Hematologi) } & \multicolumn{1}{c}{$\begin{array}{c}\text { Kontrol 30 hari } \\
(\mathrm{n}=6)\end{array}$} & $\begin{array}{c}\text { Perlakuan 30 hari } \\
(\mathrm{n}=6)\end{array}$ & \multirow{2}{*}{ Nilai $\mathrm{p}$} \\
\cline { 2 - 3 } & \multicolumn{1}{c}{ Mean \pm SD } & \multicolumn{1}{c}{ Mean \pm SD } & \\
\hline WBC( White Blood Cell) & $8.85 \pm 2.02$ & $6.83 \pm 1.75$ & $0.094^{*}$ \\
LYM(Limfosit) & $63.18 \pm 2.83$ & $67.57 \pm 4.19$ & $0.060^{*}$ \\
MON(Monosit) & $4.53 \pm 1.91$ & $5.43 \pm 2.27$ & $0.474^{*}$ \\
NEU(Neutrofil) & $32.32 \pm 1.49$ & $27.00 \pm 2.73$ & $0.002^{*}$ \\
EOS(Eosinofil) & $0.00 \pm 0.00$ & $0.00 \pm 0.00$ & $1.000^{* *}$ \\
BAS(Basofil) & $0.00 \pm 0.00$ & $0.00 \pm 0.00$ & $1.000^{*}$ \\
RBC(Red Blood Cell) & $9.45 \pm 0.24$ & $9.00 \pm 0.21$ & $0.006^{*}$ \\
HGB(Hemoglobin) & $17.20 \pm 0.50$ & $16.50 \pm 0.99$ & $0.154^{*}$ \\
HCT(Hematokrit) & $36.94 \pm 0.87$ & $36.80 \pm 2.34$ & $0.892^{*}$ \\
MCV(Mean Corpuscular Volume) & $39.00 \pm 1.26$ & $40.83 \pm 1.94$ & $0.081^{*}$ \\
MCH(Mean Corpuscular Hemoglobin) & $18.20 \pm 0.30$ & $18.32 \pm 0.73$ & $0.725^{*}$ \\
MCHC & $46.57 \pm 0.94$ & $44.87 \pm 1.12$ & $0.018^{*}$ \\
PLT(Platelet/trombosit) & $340.83 \pm 44.93$ & $358.67 \pm 51.73$ & $0.538^{*}$ \\
RDW-CV & $18.90 \pm 0.38$ & $19.05 \pm 0.32$ & $0.480^{*}$ \\
RDW-SD & $29.95 \pm 0.94$ & $31.48 \pm 1.36$ & $0.047^{*}$ \\
MPV(Mean Platelet Volume) & $5.82 \pm 0.25$ & $6.02 \pm 0.25$ & $0.193^{*}$ \\
PDW(Platelet Distribution Width) & $6.78 \pm 0.44$ & $6.77 \pm 0.34$ & $0.944^{*}$ \\
PCT(Plateletcrit) & $0.20 \pm 0.04$ & $0.22 \pm 0.04$ & $0.456^{*}$ \\
\hline
\end{tabular}

Berdasarkan tabel 1 dan 2 sebelumnya, analisis hematologi tidak menunjukkan perbedaan yang bermakna antara kelompok kontrol dan kelompok perlakuan yang diberi pencahayaan LED selama 15 hari pada malam hari. Namun pada kelompok dengan paparan pencahayaan LED selama 30 hari menunjukkan perbedaan yang signifikan, khususnya pada mean corpuscular hemoglobin Concentration (MCHC), sel darah merah (RBC), dan neutrofil dengan nilai $p$-value $<0,05$. 


\section{PEMBAHASAN}

Penelitian ini menggunakan 24 ekor tikus wistar jantan. Penelitian ini dilakukan untuk menganalisis kadar kortisol dan hematologi akibat paparan cahaya LED di malam hari selama 15 hari dan 30 hari. Kadar kortisol dilakukan dengan menggunakan metode ELISA dan kadar hematologi dilakukan dengan pemeriksaan hematologi autoanalyzer. Hasil penelitian menunjukkan kadar kortisol dan hematologi pada kelompok 15 hari secara statistik tidak terdapat hubungan yang bermakna dan kadar kortisol dan hematologi pada kelompok 30 hari secara statistik terdapat hubungan yang bermakna, khususnya untuk hematologi terdapat hubungan yang bermakna pada MCHC, RBC dan neutrophil.

Pada penelitian ini terjadi peningkatan kortisol baik pada kelompok 15 hari dan kelompok 30 hari, namun secara statistik untuk kelompok 15 hari tidak terdapat perbedaan yang signifikan, sedangkan untuk kelompok 30 hari secara statistik terdapat perbedaan yang signifikan antara kelompok yang terpapar LED dan tidak terpapar LED di malam hari. Akibat adanya paparan cahaya LED di malam hari mengakibatkan terjadinya desinkronisasi dari ritme sirkadian internal, salah satunya terjadi peningkatan sekresi glukokortikoid. Glukokortikoid berada di bawah kendali sumbu HPA dan mempunyai peran penting untuk memungkinkan organisme bisa cepat beradaptasi dengan perubahan lingkungan untuk mempertahankan homeostasis (Mohawk, Pargament, \& Lee, 2007). Dengan adanya paparan cahaya Light Emiting Diode (LED) di malam hari memberikan pengaruh terhadap hormon kortisol dan menimbulkan gangguan homeostatis hormonal pada sumbu HPA, ini dikarenakan terganggunya peran suprachiasmatic nucleus (SCN) dalam pengaturan sistem sirkadian, karena SCN turut serta dalam mengatur sekresi hormon kortisol melalui jalur sinapsis dengan paraventricular nucleus (PVN), dan akan mengaktifkan corticotropin releasing hormone (CRH) dan arginin vasopressin (AVP) melalui system vena portal CRH, AVP sehingga akan merangsang hipofisis anterior untuk menghasilkan hormone adrenokortikotropik $(\mathrm{ACTH})$, kemudian akan masuk ke aliran darah dan mengaktifkan kelenjar adrenal untuk melepaskan glukokortikoid (kortisol pada manusia dan kortikosteron pada tikus/rats), serta akan memberikan umpan balik negative dengan menghambat produksi sitokin, dan terganggunya fungsi SCN ini akibat stimulasi cahaya dari retina yang berlangsung lama atau terus-menerus sehingga berdampak terganggunya ritme sirkadian dari hormon kortisol/ kortikosterone (Neumann, Schmidt, Brockmann, \& Oster, 2019; Buijs, van Eden, Goncharuk, \& Kalsbeek, 2003; Kunugi, Hori, Adachi, \& Numakawa, 2010), salah satunya dengan terjadinya peningkatan hormon kortisol/ kortikosteron seperti pada Gambar 1. SCN menggunakan setidaknya empat jenis target neuronal untuk meneruskan sinyal sirkadiannya, yaitu melalui komunikasi langsung dengan neuron neuroendokrin, komunikasi langsung dengan neuron otonom (PVN) untuk mengkomunikasikan sinyal waktu hari ke berbagai organ tubuh, komunikasi dengan struktur hipotalamus di antaranya SCN dan PVN, seperti subPVN, dorsomedial nucleus of the hypothalamus (DMH), dan medial preoptic area (MPA), yang dapat berfungsi sebagai target perantara antara SCN dan neuroendokrin dan neuron otonom, serta komunikasi ke area luar hipotalamus, seperti lateral geniculate nucleus (LGN) dan paraventricular nucleus of the thalamus (PVT) untuk menyinkronkan perilaku yang diinduksi hipotalamus dan aktivitas lokomotor (Buijs, et al., 2003). Penelitian ini sejalan dengan penelitian yang dilakukan oleh Alves-Simoes, et al. (2016) yang mana terjadi peningkatan kadar kortisol/kortikosteron pada kelompok tikus yang dipaparkan cahaya LED selama 6 minggu atau 44 hari dibandingkan dengan tikus yang dipaparkan cahaya LED selama 2 minggu atau 14 hari dengan intensitas yang sama (Alves-Simoes, Coleman, \& Canal, 2016). Penelitian ini juga serupa dengan penelitan yang dilakukan oleh Milošević, et al. (2005) yang menunjukkan bahwa paparan cahaya konstan dalam jangka panjang meningkatkan kadar kortisol/kortikosteron dan mengakibatkan peningkatan aktivitas dari sel zona fasciculata pada kelompok perlakuan dibandingkan dengan kelompok kontrol yang dipertahankan dalam siklus 12 jam terang dan 12 jam gelap (Milošević et al., 2005; Alves-Simoes, et al., 2016). Begitupun dengan penelitian yang dilakuan Claustart, et al. (2008) dan Mohawk, et al. (2007) yang menyatakan bahwa pencahayaan terang di malam hari pada tikus dapat mengubah ritme sirkadian dari kortisol/kortikosteron sehingga menyebabkan terjadinya peningkatan kortisol/kortikosteron (Claustrat, Valatx, Harthé, \& Brun, 2008; Mohawk, et al., 2007). Adanya stressor baik stres fisik, psikologis dan sosial akan mempengaruhi HPA-axis menyebabkan peningkatan sekresi CRH oleh hipotalamus yang merangsang hipofisis menstimulasi kelenjar adrenal untuk mensekresikan kortisol dalam jumlah banyak sehingga akan menekan sistem 
imun, karena sekresi kortisol berbanding lurus dengan stres dan berbanding terbalik dengan imunitas tubuh (Kunugi, et al., 2010). Tetapi penelitian ini sedikit berbeda yang dilakukan oleh (Jung, et al., 2010) yang menemukan bahwa paparan cahaya terang menurunkan kadar kortisol, dan menyatakan bahwa paparan cahaya tidak hanya tergantung dari durasi terpapar, dan intensitasnya tetapi dari waktu/jam biologis paparan cahaya juga dapat menjadi penentu penting dari efek cahaya pada kortisol.

Pada penelitian ini juga didapatkan efek dari pemberian cahaya LED terhadap parameter hematologi menyebabkan terjadinya penurunan dari sel darah merah (RBC) dan penurunan dari konsentrasi hemoglobin eritrosit rata-rata (MCHC), ini dikarenakan adanya penurunan konsentrasi melatonin akibat paparan cahaya yang lama sebagai efek perlindungan melatonin terhadap sel-sel darah yang diperantarai mekanisme seluler dan sistemik yang kompleks, terutama kemampuan melatonin untuk menahan proses stres oksidatif, untuk melindungi membrane mitokondria dan memastikan efek anti-inflamasi dan imunomodulator dari melatonin (Makartseva, Kozlova, Kirillov, \& Areshidze, 2021). Selain itu, pengaruh paparan LED pada malam hari menyebabkan terjadinya penurunan jumlah neutrofil. Neutrofil merupakan salah satu bagian dari sistem pertahanan tubuh, yang berperan dalam pertahanan awal imunitas non spesifik terhadap infeksi bakteri, dengan adanya paparan cahaya di malam hari menyebabkan penekanan melatonin, karena sintesis dan sekresi melatonin distimulasi oleh suasana gelap dan diinhibisi oleh suasana terang sehingga adanya cahaya di malam hari bisa menyebabkan terhambatnya atau bahkan terhentinya produksi melatonin yang bisa berdampak buruk pada sistem imunitas ,karena peran dari melatonin itu sendiri dalam regulasi kekebalan adalah melatonin memiliki efek peningkatan kekebalan langsung baik pada manusia maupun hewan. Ini menandakan bahwa paparan LED di malam hari bisa memberikan efek buruk pada kesehatan dan fungsi imunitas, sehingga tubuh akan lebih rentan terhadap penyakit dan infeksi (Sandra, 2011; Tordjman, et al., 2019). Penelitian ini serupa dengan penelitian yang dilakukan Lyudmila, et al. (2020 dalam Makartseva, et al., 2021) yang menyatakan bahwa akibat paparan cahaya konstan pada tikus wistar-jantan menyebabkan perubahan pada beberapa parameter hematologi secara signifikan, salah satunya menyebabkan terjadinya penurunan mean corpuscular hemoglobin concentration (MCHC) atau konsentrasi hemoglobin eritrosit rata-rata dan red blood cell (RBC) atau sel darah merah (Makartseva, et al., 2021), tetapi sedikit berbeda dengan penelitian yang dilakuan (Hana, Eliska, Michal, Lucia, \& Zdenek, 2015) yang melaporkan bahwa paparan cahaya dengan intensitas yang tinggi pada tikus wistar jantan tidak mempengaruhi parameter hematologi, hal ini juga sebenarnya sesuai dengan penelitian ini khususnya kelompok yang dipaparkan cahaya LED selama 15 hari yang secara statistik tidak terdapat perbedaan yang signifikan atau perbedaan yang bermakna tetapi terjadi peningkatan maupun penurunan dari parameter hematologinya.

Menurut Ji, et al. (2014) cahaya tidak hanya dipengaruhi oleh intensitas dan waktu paparan tetapi juga Panjang gelombangnya. Cahaya itu sendiri merupakan faktor lingkungan utama atau isyarat utama untuk aktivitas dari suprachiasmatic nucleus (SCN), dan untuk mengaktifkan sistem sirkadian diperlukan kuantitas/intensitas, spektrum, durasi, waktu dan distribusi yang tepat (Milošević, et al., 2005; Ji, Zhao, Shen, \& Zhang, 2014). SCN yang mengatur sinkronisasi dari irama sirkadian dan bekerjasama dengan hormon melatonin untuk menyinkronkan berbagai irama sirkadian dengan siklus siang-malam 24 jam. Hormon melatonin akan membantu menyamakan irama biologis tubuh dengan sinyal siang-malam eksternal, oleh karena itu apabila ada paparan cahaya terutama di malam hari akan menyebabkan penekanan melatonin yang berdampak terganggunyan irama sirkadian kita (Sherwood, 2019; Blume, Garbazza, \& Spitschan, 2019; Cho, et al., 2015). Beberapa studi eksperimental menyatakan bahwa cahaya dapat memberikan dampak buruk terhadap kesehatan tetapi tergantung dari durasi,intensitas dan waktu biologis dari paparan cahaya itu sendiri. Paparan cahaya yang kuat memberikan lebih banyak resiko daripada paparan pada tingkat cahaya yang rendah, begitupun cahaya tingkat rendah memberikan lebih banyak resiko daripada paparan yang redup, dan paparan cahaya redup akan memberikan lebih banyak resiko daripada cahaya gelap, terutama dengan panjang gelombang biru yang memberikan pengaruh pada ritme sirkadian, cahaya biru akan menekan sekresi melatonin dan aktivitas sirkadian.

\section{SIMPULAN}

Pada penelitian ini terjadi sedikit peningkatan kortisol pada kelompok yang dipaparkan cahaya LED di malam hari selama 15 
hari, walaupun tidak terdapat perbedaan yang signifikan atau bermakna, sedangkan untuk kelompok yang dipaparkan cahaya LED di malam hari setelah ditambahkan waktu terpaparnya selama 15 hari menjadi 30 hari terjadi peningkatan kadar kortisol serum secara signifikan. Begitupun dengan parameter hematologi pada kelompok yang dipaparkan cahaya LED selama 15 hari pada malam hari terjadi peningkatan maupun penurunan walaupun

\section{DAFTAR PUSTAKA}

Alves-Simoes, M., Coleman, G., \& Canal, M. M. (2016). Effects of type of light on mouse circadian behaviour and stress levels. Laboratory Animals, 50(1), 21-29. https://doi.org/10.1177/0023677215588052

Bedrosian, T. A., \& Nelson, R. J. (2017). Timing of light exposure affects mood and brain circuits. Translational Psychiatry, 7(1). https://doi.org/10.1038/tp.2016.262

Blume, C., Garbazza, C., \& Spitschan, M. (2019). Effects of light on human circadian rhythms, sleep and mood. Somnologie, 23(3), 147156. https://doi.org/10.1007/s11818-01900215-x

Buijs, R. M., van Eden, C. G., Goncharuk, V. D., \& Kalsbeek, A. (2003). The biological clock tunes the organs of the body: Timing by hormones and the autonomic nervous system. Journal of Endocrinology, 177(1), 17-26. https://doi.org/10.1677/joe.0.1770017

Cho, Y. M., Ryu, S. H., Lee, B. R., Kim, K. H., Lee, E., \& Choi, J. (2015). Effects of artificial light at night on human health: A literature review of observational and experimental studies applied to exposure assessment. Chronobiology International, 32(9),

1294-1310. https://doi.org/10.3109/07420528.2015.10 73158

Claustrat, B., Valatx, J. L., Harthé, C., \& Brun, J. (2008). Effect of constant light on prolactin and corticosterone rhythms evaluated using a noninvasive urine sampling protocol in the rat. Hormone and Metabolic Research, 40(6), 398-403. https://doi.org/10.1055/s-2008-1065330

Fonken, L. K., Aubrecht, T. G., MeléndezFernández, O. H., Weil, Z. M., \& Nelson, R. J. (2013). Dim light at night disrupts molecular circadian rhythms and increases body weight. Journal of Biological Rhythms, 28(4), 262-271.

https://doi.org/10.1177/0748730413493862 tidak terdapat perbedaan yang signifikan atau bermakna sebaliknya pada kelompok yang dipaparkan cahaya LED selama 30 hari menurunkan jumlah sel darah merah (RBC), konsentrasi hemoglobin eritrosit rata-rata (KHER/MCHC), dan neutrofil secara signifikan. Disarankan untuk penelitian selanjutnya lebih memperhatikan durasi/waktu paparan dan intensitas cahaya/lampu LED yang akan digunakan.

Fonken, L. K., Kitsmiller, E., Smale, L., \& Nelson, R. J. (2012). Dim nighttime light impairs cognition and provokes depressivelike responses in a diurnal rodent. Journal of Biological Rhythms, 27(4), 319-327. https://doi.org/10.1177/0748730412448324

Fonken, L. K., \& Nelson, R. J. (2014). The effects of light at night on circadian clocks and metabolism. Endocrine Reviews, 35(4), 648-670. https://doi.org/10.1210/er.2013-1051

Gnocchi, D., \& Bruscalupi, G. (2017). Circadian rhythms and hormonal homeostasis: Pathophysiological implications. Biology, 6(1), 1-20. https://doi.org/10.3390/biology6010010

Hana, P., Eliska, B., Michal, K., Lucia, H., \& Zdenek, H. (2015). The Effect of Light Intensity Upon Hematological Parameters of Brown Rats' Blood. MendelNet, 2008-2011.

Ji, L., Zhao, Z., Shen, L., \& Zhang, J. (2014). Influence on mice micro circulation and blood serum spectrum characteristic induced by light sources of different type and power. Optik, 125(1), 477-481. https://doi.org/10.1016/j.ijleo.2013.07.022

Jung, C. M., Khalsa, S. B. S., Scheer, F. A. J. L., Cajochen, C., Lockley, S. W., Czeisler, C. A., \& Wright, K. P. (2010). Acute effects of bright light exposure on cortisol levels. Journal of Biological Rhythms, 25(3), 208216.

https://doi.org/10.1177/0748730410368413

Kunugi, H., Hori, H., Adachi, N., \& Numakawa, T. (2010). Interface between hypothalamic-pituitary-adrenal axis and brain-derived neurotrophic factor in depression. Psychiatry and Clinical Neurosciences, 64(5), 447-459. https://doi.org/10.1111/j.14401819.2010.02135.x

Makartseva, L., Kozlova, M., Kirillov, Y., \& Areshidze, D. (2021). The effect of 
constant lighting on the organization of circadian rhythms of hematological parameters in wistar rats at age of 6 months. International Journal of Pharmaceutical Sciences and Research, 12(3), 1933-1938.

https://doi.org/10.13040/IJPSR.0975-

8232.12(3).1933-38

Milošević, V., Trifunović, S., Sekulić, M., ŠošićJurjević, B., Filípović, B., Negić, N., ... Starčević, V. (2005). Chronic exposure to constant light affects morphology and secretion of adrenal zona fasciculata cells in female rats. General Physiology and Biophysics, 24(3), 299-309.

Mohawk, J. A., Pargament, J. M., \& Lee, T. M. (2007). Circadian dependence of corticosterone release to light exposure in the rat. Physiology and Behavior, 92(5), 800806.

https://doi.org/10.1016/j.physbeh.2007.06.009

Nelson, R. J., \& Chbeir, S. (2018). Dark matters: Effects of light at night on metabolism. Proceedings of the Nutrition Society, 77(3), 223-229.

https://doi.org/10.1017/S0029665118000198

Neumann, A. M., Schmidt, C. X., Brockmann, R. M., \& Oster, H. (2019). Circadian regulation of endocrine systems. Autonomic Neuroscience: Basic and Clinical, 216(September 2018), 1-8. https://doi.org/10.1016/j.autneu.2018.10.001

Opperhuizen, A. L., Stenvers, D. J., Jansen, R. D., Foppen, E., Fliers, E., \& Kalsbeek, A. (2017). Light at night acutely impairs glucose tolerance in a time-, intensity- and wavelength-dependent manner in rats. Diabetologia, 60(7), 1333-1343. https://doi.org/10.1007/s00125-017-4262-y

Rohling, J. H. T., vanderLeest, H. T., Michel, S., Vansteensel, M. J., \& Meijer, J. H. (2011). Phase resetting of the mammalian circadian clock relies on a rapid shift of a small population of pacemaker neurons. $\begin{array}{lll}P L O S & \text { ONE, } & \text { 6(9), 16-18. }\end{array}$ https://doi.org/10.1371/journal.pone.0025437

Rumanova, V. S., Okuliarova, M., \& Zeman, M. (2020). Differential effects of constant light and dim light at night on the circadian control of metabolism and behavior. International Journal of Molecular Sciences, 21(15), 1-20. https://doi.org/10.3390/ijms21155478

Russart, K. L. G., \& Nelson, R. J. (2018). Artificial light at night alters behavior in laboratory and wild animals. Journal of Experimental Zoology Part A: Ecological and Integrative Physiology, 329(8-9), 401408. https://doi.org/10.1002/jez.2173

Sandra, Y. (2011). Melatonin dan Kanker Payudara. Majalah Kesehatan Pharmamedika, 3(2), 286-291. http://academicjournal.yarsi.ac.id/index.ph p/majalah-Pharamedika/article/view/450

Sherwood, L. (2019). Introduction to Human Physiology. Cengage learning

Tähkämö, L., \& Halonen, L. (2015). Life cycle assessment of road lighting luminaires Comparison of light-emitting diode and high-pressure sodium technologies. Journal of Cleaner Production, 93, 234-242. https://doi.org/10.1016/j.jclepro.2015.01.025

Tähkämö, L., Martinsons, C., Ravel, P., Grannec, F., \& Zizzis, G. (2014). Solid State Lighting Annex: Life Cycle Assessment of Solid State Lighting.CiteSeer.

Tordjman, S., Chokron, S., Delorme, R., Charrier, A., Bellissant, E., Jaafari, N., ... Perdana. (2019). Protective role of melatonin on retinal ganglionar cell: In vitro an in vivo evidences. Life Sciences, 15(9), 1689-1699. https://doi.org/10.2174/1570159X14666161 228122

Vinogradova, I., \& Anisimov, V. (2013). Melatonin prevents the development of the metabolic syndrome in male rats exposed to different light/dark regimens. Biogerontology, 14(4), 401-409. https://doi.org/10.1007/s10522-013-9437-4 Welsh, P., Doolin, O., Mcconnachie, A., Boulton, E., Mcneil, G., Macdonald, H., ... Sattar, N. (2012). Calcium Associations with Incident Cardiovascular Disease and Mortality: The MIDSPAN Family Study. Journal of Clinical Endocrinology \& Metabolism, 97(12), 4578-4587. https://doi.org/10.1210/jc.2012 